\title{
Climate-driven changes in lake conditions during late MIS 3 and MIS 2: a high-resolution geochemical record from Les Echets, France
}

\author{
DANIEL VERES ${ }^{1,2}$, ELISABETH LALLIER-VERGÈS ${ }^{3}$, BARBARA WOHLFARTH ${ }^{4}$, TERRI LACOURSE ${ }^{5}$ \\ DIDIER KÉRAVIS ${ }^{3}{ }^{,}$, SVANTE BJÖRCK $^{6}$, FRANK PREUSSER ${ }^{7}$, VALÉRIE ANDRIEU-PONEL ${ }^{8}$ AND LINDA \\ AMPEL ${ }^{2}$ \\ 1 'Emil Racovita' Speleological Institute, Clinicilor 5, 400006 Cluj, Romania, \\ 2 Department of Physical Geography and Quaternary Geology, Stockholm University, SE-10691 Stockholm, \\ Sweden, \\ ${ }^{3}$ Institut des Sciences de la Terre d'Orléans, UMR 6113 CNRS Université d'Orléans, 1A rue de la Férollerie, \\ 45071 Orléans Cedex, France, \\ ${ }^{4}$ Department of Geology and Geochemistry, Stockholm University, SE-10691 Stockholm, Sweden, \\ ${ }^{5}$ University of Victoria, Department of Geography, Victoria, BC, V8W 3R4 Canada, \\ ${ }_{7}^{6}$ Lund University, Department of Geology, GeoBiosphere Science Centre, SE- 22362 Lund, Sweden, \\ 7 Institut für Geologie, Universität Bern, Baltzerstrasse 1+3, 3012 Bern, Switzerland, \\ ${ }^{8}$ Institut Méditerranéen d'Ecologie et de Paléoécologie (IMEP, UMR 6116 CNRS), Europôle Méditerranéen de \\ I'Arbois, BP 80, F-13545 Aix-en-Provence Cedex, France \\ Daniel Veres (e-mail: danveres@hasdeu.ubbcluj.ro)
}

\section{ABSTRACT}

Ice-core (Dansgaard et al. 1993; Johnsen et al. 2001; NGRIP members 2004) and marine sediment records (Bond et al. 1992; Moreno et al. 2004; Rasmussen \& Thomsen 2004) spanning the last glacial cycle provide compelling evidence of multiple reorganizations of the climatic system triggered by changes thought to originate in the North Atlantic region (Broecker et al. 1992; Clark et al. 2002). Sudden shifts in air temperature from a cool climate to interstadial values, known as Dansgaard-Oeschger events (DO), have been active most notably during Marine Isotope Stage (MIS) 3. Abrupt and large in amplitude, DO cycles operated on a millennial to centennial time scale and are best expressed in the North Atlantic region (Dansgaard et al. 1993; Allen et al. 1999; NGRIP members 2004; Moreno et al. 2005; Grimm et al. 2006; Wohlfarth et al. 2008), though recent research suggests that these events were probably important on a global scale (e.g. Voelker et al. 2002). Iceberg surges, known as Heinrich events (H events), appear in marine records as sudden cold spells associated with a drastic reduction in sea surface temperature, a southern shift of the Polar Front, disruption of North Atlantic thermohaline circulation and substantial delivery of ice-borne detritus to the open ocean, reaching as far south as Portugal (Bond et al. 1992; Broecker et al. 1992; Bard et al. 2000; Hemming 2004).

On the European mainland, lake sediments are the most promising archives for recording long-term and short-term climatic changes (Voelker et al. 2002). The few long lacustrine records from continental Europe show that, on a broad scale, longterm palaeoclimate variations are expressed clearly through changes in vegetation composition and dynamics (Woillard \& Mook 1982; de Beaulieu \& Reille 1984; Guiot et al. 1989; Allen \& Huntley 2000; de Beaulieu et al. 2001; Guiter et al. 2003).

However, in the context of abrupt climate change (e.g. for most of MIS 3), only limited palaeoecological information is available: most of the data come from sites located on the southern peninsulas of Mediterranean Europe (Voelker et al. 2002). It has been suggested that changes in plant cover varied in this region in concert with climatic fluctuations recorded in Greenland ice cores, with a diverse range of thermophilous taxa present at any time (Allen et al. 1999; Sánchez Goñi et al. 2002; Tzedakis et al. 2004). Much less floristic variability is seen, however, during MIS 3-2 
in pollen records from sites located north of the main mountain ranges of central and northern Europe. Here, data from peat deposits (Behre 1989; Preusser 2004), lacustrine sediments (Woillard \& Mook 1982; de Beaulieu \& Reille 1984; Helmens et al. 2000; Müller et al. 2003; Sirocko et al. 2005; Engels et al. 2008) and terrestrial proxies in marine cores (Sánchez Goñi et al. 2008) reveal long cold intervals interrupted sporadically by weakly expressed interstadials marked by rises in boreal tree pollen (Allen \& Huntley 2000; Guiter et al. 2003). Such significant differences in ecological responses point to strong regional and local climatic gradients associated with these events, issues that are not sufficiently considered when inferring synchronicity of events between various records.

In order to improve the understanding of how the European mainland was affected by rapid climate changes, we show that important palaeoecological information can be extracted from geochemical lake records (e.g. Lallier-Vergès et al. 1993; Bernasconi et al. 1997; Meyers 1997; Dean 1999; Meyers \& Lallier-Vergès 1999; Meyers \& Teranes 2001; Talbot 2001; Leng et al. 2005). Les Echets (Fig. 1A, B) is situated in a region sensitive to current climate changes at the boundary between humid Atlantic air masses and Mediterranean influences. The physical and chemical properties of the former lake and catchment area underwent significant changes on millennial to centennial time scales, changes that we attempt to quantify in palaeoenvironmental terms through multi-proxy geochemical analyses of the organic fraction within sediments. We demonstrate that the region was greatly influenced by the rapid climate variability specific to MIS 3, as seen in marine sediments (Bond et al. 1992; Moreno et al. 2004; Rasmussen \& Thomsen 2004; Sánchez Goñi et al. 2008) or ice cores (Johnsen et al. 2001; NGRIP members 2004) hundreds of kilometres away.

\section{Depositional setting, lithostratigraphic units and chronology}

Les Echets $\left(45^{\circ} 54^{\prime} \mathrm{N}, 4^{\circ} 56^{\prime} \mathrm{E}\right)$ is a large $\left(\sim 13 \mathrm{~km}^{2}\right)$, overgrown, palaeo-lake located $\mathrm{c}$. $15 \mathrm{~km}$ northeast of Lyon, France (Fig. 1A, B). Its watershed extended over $40 \mathrm{~km}^{2}$ in a glacier terminus landscape formed during the Rissian (MIS 6) and pre-Rissian glaciations (de Beaulieu \& Reille 1984 and references therein). The catchment consists mainly of unconsolidated late Quaternary glaciofluvial sediments locally covered by thick loess deposits. The surface of the mire is currently at $267 \mathrm{~m}$ a.s.I. and the basin itself contains $60-65 \mathrm{~m}$ of post-Rissian lacustrine sediments and peat.

The site was not overridden by the Alpine Würmian glaciers, but the basin was ultimately filled during the Late Würmian and an extensive peat bog formed during the Holocene. Artificial drainage of the peat bog started during the Medieval Period (de Beaulieu \& Reille 1984) and agricultural activities greatly affected the surrounding vegetation and uppermost sediment.

Two new long cores (EC1 and EC3; Fig. 1B) were mechanically recovered in 2001 and a comprehensive lithological description and correlation between the two sequences is presented in Veres et al. (2007). Core EC1 was retrieved from the central and deepest part of the basin (Fig. 1B), $700 \mathrm{~m}$ from core EC3 (Veres et al. 2008). Core EC1 is $44 \mathrm{~m}$ in length and consists of thick alternations of silts and organic-rich sediments in the lower and middle sections and faintly laminated clayey gyttja silts in the upper $15 \mathrm{~m}$. The sequence was subdivided into lithostratigraphic units based on sediment visual appearance, sedimentary structures, grain size and 
organic matter content (Veres et al. 2007). The down-core lithological variations, clearly reflected in the organic content, are also closely replicated by changes in all geochemical proxies (Fig. 2). Therefore, in interpreting the geochemical data we follow the same unit subdivision. All analyses presented in this article were performed on core EC1 between 30.06 and $3.31 \mathrm{~m}$ depth (Figs 2, 3).

The age model follows Wohlfarth et al. (2008) and is based on 48 radiocarbon ages on terrestrial and limnic/riparian plant macrofossils, pollen concentrates and bulk sediment. Additionally, 22 luminescence (IRSL) age estimates were obtained on the polymineral fine-grain fraction $(4-11 \mu \mathrm{m})$ using the modified single-aliquot regenerative-dose protocol of Preusser (2003). The age model (for more details see Wohlfarth et al. 2008) was constructed using the Bayesian software Bpeat of Blaauw \& Christen (2005). All ages discussed in the text are in calendar years.

According to the age model, the sequence presented in this study covers the time interval from c. $46.1 \mathrm{kyr}$ BP at $30.06 \mathrm{~m}$ depth to $c$. $15.0 \mathrm{kyr}$ BP at $5.49 \mathrm{~m}$ depth (Figs 2, 3). Unit $H(30.06-27.48 \mathrm{~m})$ covers the time interval from 46.1 to $36.1 \mathrm{kyr} B P$, with several large hiatuses (Fig. 2). Unit G $(27.48-22.49 \mathrm{~m}$ ) is dated to 36.1-31.6 kyr BP, unit $F(22.49-18.55 \mathrm{~m})$ to $31.6-27.8 \mathrm{kyr} B P$, unit $E(18.55-16.20 \mathrm{~m})$ to $27.8-26.4 \mathrm{kyr}$ $B P$, unit $D(16.20-11.55 \mathrm{~m})$ to $26.4-18.6 \mathrm{kyr} B P$ and unit $\mathrm{C}(11.55-5.91 \mathrm{~m})$ to $18.6-$ $15.5 \mathrm{kyr}$ BP. In unit B (5.91-3.31 m), the age model extends only to $5.49 \mathrm{~m}$, where we obtained a modelled age of $15.0 \mathrm{kyr}$ BP. No age estimates are available between 5.49 and $3.31 \mathrm{~m}$ depth, but most likely the core is not older than 14-15 kyr BP, since palynological investigations of core $\mathrm{G}$ recovered from the same area as EC1 (Fig. 1B), suggested that the Les Echets basin was already filled-in during the early part of the last Termination (de Beaulieu \& Reille 1984).

\section{Methods}

\section{Loss-on-ignition parameters}

For loss-on-ignition analyses, the sediment was sampled volumetrically in contiguous $2 \mathrm{~cm}$ increments (occasionally $1.5 \mathrm{~cm}$ ) without crossing lithological boundaries. The sediment was combusted for $4 \mathrm{~h}$ at $550{ }^{\circ} \mathrm{C}$, to estimate organic matter content (OM), and then $925^{\circ} \mathrm{C}$, to estimate inorganic carbon content (IC). The minerogenic content (MM) represents the detrital residue (including siliceous microfossils) remaining after combusting the samples at $925^{\circ} \mathrm{C}$. All parameters are given as percentage (\%) loss of the dry weight (Heiri et al. 2001). Dry density (DD) was calculated as the dry mass of the sample divided by its wet volume and is expressed as $\mathrm{g} \mathrm{cm}^{-3}$.

\section{Organic matter carbon and nitrogen elemental and isotopic analyses}

The organic carbon and total nitrogen concentrations were determined on a Carlo Erba NC2500 elemental analyser using freeze-dried and homogeneously ground sediment samples of $2 \mathrm{~cm}$ increments. The core was generally subsampled every $5 \mathrm{~cm}$, but with finer sampling in sections displaying marked lithological changes. Prior to the total organic carbon $\left(\mathrm{C}_{\text {org }}\right)$ analysis, the sediment was treated with $2 \mathrm{~N} \mathrm{HCl}$ to remove carbonates. The residual nitrogen $\left(\mathrm{N}_{\text {tot }}\right)$ was determined before carbonate removal. The relative error was $<1 \%$ for both measurements. The $\mathrm{C}_{\text {org }} / \mathrm{N}_{\text {tot }}$ ratios were calculated from the mean $\mathrm{C}_{\text {org }}(\%)$ and $\mathrm{N}_{\text {tot }}(\%)$ and multiplied by 1.167 to yield $\mathrm{C}_{\text {org }} / \mathrm{N}_{\text {tot }}$ atomic ratios (Meyers \& Teranes 2001). 
Organic matter carbon and nitrogen stable isotopes were determined with a Finnigan MAT Delta ${ }^{\text {plus }}$ mass spectrometer coupled with the elemental analyzer. The isotopic analysis was done in two steps: $\delta^{15} \mathrm{~N}_{\text {tot }}$ values were determined on the chemically untreated sediment, while the $\delta^{13} \mathrm{C}_{\text {org }}$ was measured after carbonate removal. Reproducibility is estimated to better than $0.15 \%$ for both measurements. The $\delta^{13} \mathrm{C}_{\text {org }}$ is given relative to the Vienna PeeDee Belemnite (VPDB) standard and $\delta^{15} N_{\text {tot }}$ is expressed relative to atmospheric dinitrogen.

\section{Rock-Eval pyrolysis}

Samples of about $80 \mathrm{mg}$ of dried (at $40{ }^{\circ} \mathrm{C}$ ) and ground sediment were used for determining organic matter oxygen $(\mathrm{OI})$ and hydrogen $(\mathrm{HI})$ indices using a Rock-Eval Turbo 6 device. The analysis followed two steps: a pyrolysis phase during which the sediment sample was heated under a nitrogen atmosphere (between 200 and $650^{\circ} \mathrm{C}$ ) and an oxidation phase under an air stream (between 400 and $850{ }^{\circ} \mathrm{C}$ ). Both phases were performed under a stepwise controlled rise in temperature, which permitted the identification of a suite of organic components (e.g. $\mathrm{HC}, \mathrm{CO}, \mathrm{CO}_{2}$ ) produced during the process (Lafargue et al. 1998). HI represents the hydrocarbonaceous products liberated per gram of $\mathrm{C}_{\text {org }}\left(\mathrm{mg} \mathrm{HC} \mathrm{g}^{-1} \mathrm{C}_{\text {org }}\right)$ during the pyrolytic phase, while $\mathrm{OI}$ represents milligrams of $\mathrm{CO}_{2}$ produced per gram of $\mathrm{C}_{\text {org }}(\mathrm{mg}$ $\mathrm{CO}_{2} \mathrm{~g}^{-1} \mathrm{C}_{\text {org }}$ ) below $390{ }^{\circ} \mathrm{C}$, during the pyrolytic phase. Details of this method and applications to palaeolimnology are described thoroughly in Lafargue et al. (1998), Meyers \& Lallier-Vergès (1999) and Jacob et al. (2004).

\section{Results and discussion}

\section{Productivity variations in Les Echets as indicators of climatic events}

Percentages of organic matter, $\mathrm{C}_{\text {org }}$ and $\mathrm{N}_{\text {tot }}$ are normally used in palaeolimnology for describing lake productivity in general terms, and recognize climatic events. The quantity of organic matter preserved in lake sediments depends largely on the organic sedimentation rate and the degree of biological/chemical degradation during transport, burial and postdepositional remineralization (Bertrand \& Lallier-Vergès 1993; Patience et al. 1996; Meyers 2003). At Les Echets, $C_{\text {org }}$ content is extremely low in unit $\mathrm{H}(1 \%-2 \%)$, but increases to $3 \%-12 \%$ in the silty gyttjas of unit $\mathrm{G}$ (Fig. 2). $\mathrm{C}_{\text {org }}$ contents in units $\mathrm{F}$ and $\mathrm{E}$ are $c .5 \%$ in the clayey silt gyttjas, but only $2 \%-3 \%$ in the clayey gyttja silt layers. At the onset of unit $\mathrm{D}, \mathrm{C}_{\text {org }}$ decreases to around $1 \%$, a trend more or less maintained to the top of the sequence. $\mathrm{N}_{\text {tot }}$ closely mirrors the trend in $\mathrm{C}_{\text {org }}$, with values oscillating between $0.2 \%$ in the clayey gyttja silts and $0.8 \%$ in the silty gyttjas. From $15 \mathrm{~m}$ upwards, $\mathrm{N}_{\text {tot }}$ are stable around medium to low values, while IC oscillates between $3 \%$ and $15 \%$, reflecting the lithological composition of units $C$ and $B$, i.e. partly oxidized and faintly laminated, calcareous clayey gyttja silts (Fig. 2).

The lithological variations, which are closely followed by changes in organic matter, $\mathrm{C}_{\text {org }}$ and $\mathrm{N}_{\text {tot }}$ contents, have been shown by Wohlfarth et al. (2008) to reflect the lacustrine sedimentary expression of rapid climate variability during late MIS 3 and most of MIS 2. The trends in $\mathrm{C}_{\text {org }}, \mathrm{N}_{\text {tot }}$ and organic matter stable isotopes (Figs 2, 3), as well as significant correlations between these proxies (Fig. 4), suggest that they reflect productivity variations. Therefore, we interpret the silty gyttja layers as reflecting interstadial conditions, i.e. relatively moist and warm climates during which the lake was productive (Wohlfarth et al. 2008). Nonetheless, it should be taken into 
account that the concentration of organic matter in lake sediments is also related to the rate of delivery of mineral detritus fraction which can dilute the organic fraction or inhibit primary productivity. Detrital minerogenic particles comprise over $90 \%$ of the sediment in Les Echets core EC1, with the exception of the silty gyttja layers in units $G$ and $F$ and the carbonate sediments of unit $B$, where it accounts for $70 \%-80 \%$ of the bulk sediment (Fig. 2). Such high values show that the sequence of EC1 is overall highly minerogenic, a fact also reflected in the record of dry density (DD) (Fig. 2). DD shows high and oscillatory values in unit $\mathrm{H}$, repeated changes between low and high values in units $\mathrm{G}-\mathrm{E}$ in accordance with lithological changes, and medium to high values in units D-B. The minerogenic horizons (clayey gyttja silts) have been interpreted as representing periods of limited primary production due to less favourable climatic conditions during DO stadials and $\mathrm{H}$ events (Wohlfarth et al. 2008) (Figs 2, 3).

\section{Sources of sediment organic matter based on $\mathrm{C}_{\text {org }} / \mathrm{N}_{\text {tot }}$ and stable isotopes} Bulk sediment $\mathrm{C}_{\text {org }} / \mathrm{N}_{\text {tot }}$ ratios are widely used in palaeolimnology for assessing the abundance of terrestrial and aquatic components of organic matter, useful criteria for inferring past lake productivity and climate-related changes in vegetation communities in and around a lake (Meyers \& Lallier-Vergès 1999; Talbot \& Lærdal 2000 ). Overall, low $C_{\text {org }} / N_{\text {tot }}$ ratios (<10) for most of our record indicate that algal productivity dominated input of organic matter to the sediments (Fig. 2). A few intervals in units $G$ to $E$ (silty gyttjas) show $C_{\text {org }} / N_{\text {tot }}$ between 10 and 22 , values likely reflecting mixed lacustrine and terrestrial contribution to the organic matter pool. Although various biochemical constituents of both terrestrial and algal organic matter could be severely affected by diagenesis, the general elemental signature of sources is usually preserved after sedimentation (Meyers \& Lallier-Vergès 1999). Therefore, the major concern in the use of $\mathrm{C}_{\text {org }} / \mathrm{N}_{\text {tot }}$ in the present study is the contribution (if any) of inorganically bound nitrogen to this ratio. Although we had no analytical means in determining the inorganic nitrogen content, a strong correlation between $\mathrm{C}_{\text {org }}$ and $\mathrm{N}_{\text {tot }}$ (Fig. 4B) suggests that most of the $\mathrm{N}_{\text {tot }}$ in EC1 is organically bound. Biasing of the $\mathrm{N}_{\text {tot }}$ values by inorganic nitrogen is of major concern for sediments with $<0.3 \% \mathrm{C}_{\text {org }}$ (Meyers \& Lallier-Vergès 1999). Nevertheless, we can use the regression line (cf. Talbot 2001) in Fig. 4B and estimate that a small portion of $\mathrm{N}_{\text {tot }}$ might be derived from inorganic forms. However, we have chosen not to subtract these values without analytical control, as doing so might result in incorrect $\mathrm{C}_{\text {org }} / \mathrm{N}_{\text {tot }}$ ratios, i.e. most $N_{\text {tot }}$ contents in unit $H$ will be negative. Moreover, the $C_{\text {org }} / N_{\text {tot }}$ interpretation is fully supported by estimates of algal palaeoproductivity based on biogenic silica analysis and diatom flora distribution in the same core (Ampel et al. 2008). Ongoing organic petrography and biomarker analyses are expected to provide results for validating/invalidating the use of $\mathrm{C}_{\text {org }} / \mathrm{N}_{\text {tot }}$ for inferring sources of organic matter at Les Echets.

The rapid lithological changes are also clearly expressed in $\delta^{13} \mathrm{C}_{\text {org }}$, which shows large isotopic shifts (8\%o-10\%) between lithological horizons (Figs 2, 3). The most depleted values (-25\% to $-28 \%$ ) are found in unit $\mathrm{H}$, as a whole, and in units $\mathrm{F}$ (22.54-21.82 m; 31.7-30.9 kyr BP) and D (14.88-16.18 m; 23.5-26.4 kyr BP), i.e. sediments with very low $\mathrm{C}_{\text {org }}$. The other carbon-poor intervals (clayey gyttja silts) show values between $-22 \%$ and $-25 \%$, while $\delta^{13} \mathrm{C}_{\text {org }}$ is progressively enriched in the silty gyttjas to values as high as $-18 \%$ o to $-16 \%$ (Figs $2,5 \mathrm{~A}$ ). While the $\mathrm{C}_{\text {org }} / \mathrm{N}_{\text {tot }}$ ratios indicate a mixture of algal and C3 land plant material, the $\delta^{13} \mathrm{C}_{\text {org }}$ in the silty gyttjas is 
outside the ranges defined for such organic matter sources (Fig. 5A). These observations imply that the more carbon-rich the sediment is, the more enriched is its organic matter isotopic composition, reaching values characteristic of $\mathrm{C} 4$ terrestrial plants (i.e. $-9 \%$ to $-17 \%$; Leng et al. 2005). As C4 plants are mostly adapted to arid and warm climates, a contribution of this type of material to the organic pool at Les Echets is very unlikely during the studied interval. Therefore, we presume that biogeochemical changes related to increased primary productivity are responsible for the enriched $\delta^{13} \mathrm{C}_{\text {org }}$ values in the silty gyttjas (Meyers 1997; Fuhrmann et al. 2003 and references therein). According to Talbot \& Lærdal (2000), two factors are of great importance in controlling the isotopic composition of aquatic organic matter, namely the isotopic range of the dissolved inorganic carbon pool and isotopic effects related to the availability of dissolved $\mathrm{CO}_{2}$ in the lake water. Moreover, variables such as rapid changes in species composition and growth rate (Ficken et al. 1998), varying $\mathrm{pCO}_{2}$ (Street-Perrott et al. 2004) and diagenesis (Lehmann et al. 2002) have also been shown to complicate the interpretation of bulk $\delta^{13} \mathrm{C}_{\text {org }}$ values (Meyers 1997; Leng et al. 2005). During periods of enhanced aquatic productivity, which we assume was the case during deposition of the silty gyttjas, the transfer of organic matter to the hypolimnion or its rapid burial in the sediment may have triggered temporary or permanent depletion of ${ }^{12} \mathrm{C}$ in the productive surface waters, and in turn led to a progressive isotopic enrichment of the subsequently produced organic matter (Meyers 1997; Talbot \& Lærdal 2000; Meyers \& Teranes 2001; Filippi \& Talbot 2005). Similar shifts to less negative values for algal organic matter have already been reported from a number of sites, e.g. in Meyers (1997 and references therein). Significant changes of the carbon isotopic signal can also occur when the availability of dissolved $\mathrm{CO}_{2}$ decreases and aquatic producers use dissolved $\mathrm{HCO}_{3}{ }^{-}\left(\delta^{13} \mathrm{C}=1 \% \mathrm{o}\right)$ as their source of carbon (Meyers \& Lallier-Vergès 1999; Fuhrmann et al. 2003; Street-Perrott et al. 2004). Both enrichment of the dissolved inorganic carbon and the uptake of $\mathrm{HCO}_{3}{ }^{-}$during intense epilimnetic photosynthesis (when the availability of $\mathrm{CO}_{2}$ decreases) may result in the production of isotopically enriched aquatic organic matter reaching values as high as $-9 \%$ (Meyers \& Lallier-Vergès 1999), i.e. in the range of $\mathrm{C} 4$ plants. Uptake of dissolved $\mathrm{HCO}_{3}{ }^{-}$is the most likely explanation for the enriched $\delta^{13} \mathrm{C}_{\text {org }}$ values observed in the calcareous sediments of unit $B$ and for the intervals rich in carbonates in units $E$ and $D$ (Figs 2, 5A). Calcified Chara sp. identified within those intervals point to a biogenic origin for the carbonates, while low $\mathrm{C}_{\text {org }} / \mathrm{N}_{\text {tot }}$ ratios confirm that the organic matter originates mostly from in-lake sources (Figs 2, 5A).

Diagnostic evidence for the sources of organic matter may also be provided by the stable nitrogen isotopes, a proxy useful for determining past availability of nitrogen to aquatic producers (Talbot 2001; Meyers \& Teranes 2001). The isotopic composition of organically fixed nitrogen depends largely on the composition of the dissolved inorganic nitrogen pool and on the metabolic pathway which the organic matter producers follow during nitrogen assimilation (Talbot \& Lærdal 2000). Lacustrine algae that form organic matter using dissolved nitrate $\left(\mathrm{NO}_{3}^{-}\right)$have $\delta^{15} \mathrm{~N}$ values between $7 \%$ and $10 \%$ (the $\delta^{15} \mathrm{~N}_{\text {of }} \mathrm{NO}_{3}{ }^{-}$), whereas aquatic producers and land plants that directly assimilate atmospheric nitrogen $\left(\delta^{15} \mathrm{~N}=0 \%\right.$ ) produce organic matter with values close to $0 \pm 2 \%$ (Meyers 1997; Talbot \& Lærdal 2000).

The high $\delta^{15} \mathrm{~N}_{\text {tot }}$ in the clayey gyttja silts (7\%o-10.4\%o) in units G-E might be interpreted as resulting primarily from algal fixation of dissolved nitrate. This would 
add evidence of an algal origin of the organic matter in the clayey gyttja silts, in accordance with the $\mathrm{C}_{\text {org }} / \mathrm{N}_{\text {tot }}$ ratios, which, with values mainly of $<10$, suggest that algal biomass is the dominant source of organic matter. Interestingly, the enrichment in $\delta^{13} \mathrm{C}_{\text {org }}$ coincides with depletion in $\delta^{15} \mathrm{~N}_{\text {tot }}$ from around $8 \%$ to $10.4 \%$ in the clayey gyttja silts to less than $5 \%$ in the silty gyttjas (Figs 2, 4E). Such depletion in $\delta^{15} \mathrm{~N}_{\text {tot }}$ over a productive interval might actually result from restricted availability of dissolved nitrogen following intense algal production, rapid sedimentation and limited remineralization of organic matter during/after burial (Meyers 1997; Talbot \& Lærdal 2000; Meyers \& Teranes 2001). However, the lack of correlation between $\delta^{15} \mathrm{~N}_{\text {tot }}$ and $\mathrm{N}_{\text {tot }}$ (Fig. 2) confirms that the processes behind nitrogen biochemical dynamics in lakes are complicated by a multitude of factors which can affect the nitrogen cycle (see review in Talbot 2001; Lehmann et al. 2002), and therefore interpretation of the data is not straightforward (Meyers \& Teranes 2001; Leng et al. 2005). Overall, $\delta^{15} \mathrm{~N}_{\text {tot }}$ is generally more depleted in units $G$ to $E$ (clayey gyttja silts) and enriched in units $D$ to $B$, while unit $H$ and the silty gyttjas in units $G$ to $E$ exhibit medium values (Fig. 2). Such differences may occur because of changes in nitrogen availability in the surface waters, shifts in fixation patterns, changes in phytoplankton assemblages and/or organic matter sources (lacustrine or terrigenous), or due to the release of nitrogenous compounds after organic matter incorporation into the sediment (Talbot \& Lærdal 2000). An alternative explanation for the low $\delta^{15} \mathrm{~N}_{\text {tot }}$ values in the silty gyttjas (Fig. 2) might be that they indicate periods of soil leaching and delivery of terrestrial organic material to the lake, processes that could have depressed the $\delta^{15} \mathrm{~N}_{\text {tot }}$ to values showing a mixture of algal and terrestrial organic matter. Soil organic matter has typical $\delta^{15} \mathrm{~N}_{\text {tot }}$ values of around $5 \%$, while $\mathrm{C}_{\text {org }} / \mathrm{N}_{\text {tot }}$ higher than 10 in the silty gyttjas indicate contributions of higher-plant detritus rich in cellulose to the sediment.

Above $16.90 \mathrm{~m}(<27.1 \mathrm{kyr} \mathrm{BP}) \delta^{15} \mathrm{~N}_{\text {tot }}$ drops and oscillates in a narrow range between $0.6 \%$ and $3.9 \%$ (units $\mathrm{D}-\mathrm{B}$ ). It is possible that these values reflect a major change in biota composition, with direct fixers of atmospheric nitrogen becoming the dominant organic matter producers, in contrast to the nitrogen dynamics in the underlying units (Fig. 2). Shifts to low $\delta^{15} \mathrm{~N}_{\text {tot }}(3 \%$ ) for aquatic-derived organic matter in a Late Pleistocene sequence from Lake Victoria have been interpreted by Talbot \& Lærdal (2000) as an indication of enhanced atmospheric nitrogen fixation by aquatic communities. Nevertheless, low $\delta^{15} N_{\text {tot }}$ values in units $D$ and $C$ may on the other hand derive (at least partially) from the incorporation of degraded terrestrial organic matter washed-in from the watershed; however, this interpretation is in conflict with the low $\mathrm{C}_{\text {org }} / \mathrm{N}_{\text {tot }}$ ratios and relatively high hydrogen index $(\mathrm{HI})$ contents in sediments above $16.90 \mathrm{~m}$. Figure 4B shows that relatively low $\mathrm{C}_{\text {org }}$ values are associated with medium $N_{\text {tot }}$ values; it is possible that some inorganic nitrogen depresses the $C_{\text {org }} / N_{\text {tot }}$ ratios to the extremely low values observed during this period. In other words, the terrestrial component in the $\mathrm{C}_{\text {org }} / \mathrm{N}_{\text {tot }}$ ratios may be underestimated in these sediments.

\section{Sources and preservation of sediment organic matter based on hydrogen and oxygen indices}

Autochthonous lacustrine organic material deposited and preserved in an oxygenpoor environment will normally exhibit high (>600 $\mathrm{mg} \mathrm{HC} \mathrm{g}^{-1} \mathrm{C}_{\text {org }}$ ) HI values (Talbot \& Lærdal 2000). Following lake-level lowering or increased oxygen availability in the 
water column due to changing mixing regimes or at the water-sediment interface, algal organic matter is progressively oxidized during sinking and sedimentation (Ariztegui et al. 2001; Jacob et al. 2004). In such cases, $\mathrm{C}_{\text {org }}$ and $\mathrm{HI}$ decrease to very low values, while the oxygen content progressively increases as a function of oxidation strength (Meyers 1997). In many circumstances, algal organic matter can become highly degraded under oxygenated conditions to produce low $\mathrm{HI}$ and high $\mathrm{OI}$ values characteristic of terrestrial organic matter, leading to complications of source assignments (Patience et al. 1996; Sifeddine et al. 1996).

High $\mathrm{HI}$ values (400-700 mg HC g ${ }^{-1} \mathrm{C}_{\text {org }}$ ) in the silty gyttjas (Figs 2,3 ) suggest that sediment organic matter in these layers is rich in hydrogenous compounds which could derive mostly from algal biomass and/or from microbial biomass, and to a lesser extent also from the waxy material of higher plants (Meyers \& Lallier-Vergès 1999; Talbot \& Lærdal 2000; Lüniger \& Schwark 2002). Support for a dominant algal origin in the silty gyttjas is provided by the $\delta^{13} \mathrm{C}_{\text {org }}$, which show the most enriched values when $\mathrm{HI}$ is high (Fig. $4 \mathrm{~F}$ ), although intermediate $\mathrm{C}_{\text {org }} / \mathrm{N}_{\text {tot }}$ ratios in the same horizons point also to a terrestrial component in the sediment.

High Ol values (>200 mg CO $2 \mathrm{~g}^{-1} \mathrm{C}_{\text {org }}$ ), on the other hand, are regarded as representing the contribution of oxygen-rich organic matter originating mainly from land-derived plant debris (Wilkes et al. 1999; Dean 2006). Most of the minerogenicrich intervals in units $\mathrm{H}$ and $\mathrm{F}-\mathrm{D}$ have medium to very high $\mathrm{Ol}$ (Figs 2, 3, 5B). These intervals also produced $\mathrm{HI}$ values of $<400 \mathrm{mg} \mathrm{HC} \mathrm{g}^{-1} \mathrm{C}_{\text {org }}$ (and in some instances of $<250 \mathrm{mg} \mathrm{HC} \mathrm{g}{ }^{-1} \mathrm{C}_{\text {org }}$ ) and $\delta^{13} \mathrm{C}_{\text {org }}$ between $-24 \%$ and $-28 \%$, which could indicate the presence of terrestrial organic matter in the sediment. However, this interpretation contrasts with the low $\mathrm{C}_{\text {org }} / \mathrm{N}_{\text {tot }}$ ratios $(<10)$ in these intervals. There are a few intervals in the sequence that exhibit very high $\mathrm{Ol}\left(>500 \mathrm{mg} \mathrm{CO}_{2} \mathrm{~g}^{-1} \mathrm{C}_{\text {org }}\right.$ ) and low $\mathrm{C}_{\text {org }}$ and $\mathrm{HI}\left(100-200 \mathrm{mg} \mathrm{HC} \mathrm{g}^{-1} \mathrm{C}_{\text {org }}\right.$ ) contents, notably in unit $\mathrm{H}$ at 29.40-29.05 m (c. 45.7-45.0 kyr BP), in unit $E$ at 22.54-21.82 $\mathrm{m}$ (31.7-30.9 kyr BP) and in unit D at 14.88-16.18 $\mathrm{m}(26.4-23.5 \mathrm{kyr})$ (Figs 2, 3, 5B). Ol as presented in this study represents the $\mathrm{CO}_{2}$ released during the pyrolitic phase at temperatures below $390{ }^{\circ} \mathrm{C}$. Despite this, due to the occurrence of carbonates in the sediment, the highest $\mathrm{OI}$ values (>500 $\mathrm{mg} \mathrm{CO}_{2} \mathrm{~g}^{-1} \mathrm{C}_{\text {org }}$ ) have to be interpreted with caution, although no correlation of Ol with IC (Fig. 2), mineral carbon (Rock Eval) and CaO contents (ICP-AES) has been observed in the ongoing analyses. It is difficult to explain why such OI values occur and whether they are related to organic matter degradation or carbonate oxidation, although these high OI intervals correlate precisely with the highest dry density values. The latter proxy is commonly employed for quantifying catchment erosion and minerogenic deposition in a lake basin (Zolitschka \& Negendank 1996; Brauer et al. 2000). As such, we could argue that these intervals represent times of limited in-lake productivity, erosion and supply of terrestrial material (including also terrestrial organic matter) into the lake. It is possible that the intervals with $\mathrm{OI}$ values could be associated with the presence of highly oxidized/refractory terrestrial organic matter (Talbot \& Lærdal 2000; Fuhrmann et al. 2003). These intervals show the lowest $C_{\text {org }} / N_{\text {tot }}$ ratios in the sequence, but also the lowest $\mathrm{HI}$ values (Figs $2,3,5 \mathrm{~B}$ ). There is a possibility that $\mathrm{C}_{\text {org }} / \mathrm{N}_{\text {tot }}$ ratios (during intervals poor in $\mathrm{C}_{\text {org }}$ ) are indeed biased by inorganic nitrogen, or by the adherence to the mineral matrix of nitrogen compounds released during organic matter degradation, processes that could depress the $\mathrm{C}_{\text {org }} / \mathrm{N}_{\text {tot }}$ ratios to low values (Freudenthal et al. 2001; Lehmann et al. 2002). Therefore, we consider that 
additional optical microscopy and mineralogical investigations seem necessary for securely explaining the trends in the $\mathrm{C}_{\text {org }} / \mathrm{N}_{\text {tot }}$ ratio and hydrogen and oxygen indices over intervals with low organic content.

The occurrence of Phragmites macrofossils mainly in the clayey gyttja silts with medium to high $\mathrm{Ol}$ values suggests that the coring location was in shallower waters during their deposition (e.g. Talbot \& Livingstone 1989). Therefore, the alternating layers of silty gyttja and clayey gyttja silts probably reflect also lake level oscillations (Ampel et al. 2008), partly explaining the trends in the HI-OI plot (Fig. 5B). The lack of geomorphological evidence of major inflow or outflow suggests that the Les Echets palaeo-lake was primarily fed by precipitation or precipitation-controlled groundwater. Large variations in precipitation reconstructed for Europe in general (Sánchez Goñi et al. 2002), and Les Echets in particular (Guiot et al. 1989), during MIS 3-2 were likely associated with variations in lake size. Changing hydrodynamic properties and circulation regimes in the water column, together with rapid migration of shorelines, could have shifted the sediment limit and caused erosive events and/or changes in the contributing plant group to the organic matter pool (Talbot \& Livingstone 1989). As the lake had no significant inflow, most of the organic matter should be autochthonous as suggested by the $\mathrm{C}_{\text {org }} / \mathrm{N}_{\text {tot }}, \mathrm{HI}$ and biogenic silica data (Ampel et al. 2008), although intensification of aeolian activity during stadials may have added terrestrial organic matter (with variable degrees of degradation) to the lake. The coring location of EC1 is about $1 \mathrm{~km}$ from the closest shoreline, indicating that the palaeo-lake was large in the past $\left(>13 \mathrm{~km}^{2}\right)$. It may be that the terrigenous organic matter is actually a minor constituent of the sediment in core EC1 (as indicated by $\mathrm{C}_{\text {org }} / \mathrm{N}_{\text {tot }}$ ratios), since the core site is in a distal location at an appreciable distance from the shore (Fig. 1B). In large lakes, land-derived material typically becomes negligible beyond a few hundred metres from the shore (e.g. Lake Pyramid, Nevada; Meyers \& Teranes 2001). We consider that at the time of deposition of the silty gyttja layers the water column was most likely high and stratified (Ampel et al. 2008) and algal productivity resulted in a significant transfer of organic matter to the lake bottom. Good preservation of organic matter is inferred from the high $\mathrm{C}_{\text {org }}$ and $\mathrm{HI}$ values in those intervals (Fig. 2), both proxies pointing to enhanced organic preservation due to both high productivity and reducing environments (Bertrand \& Lallier-Vergès 1993; Ariztegui et al. 2001; Eusterhues et al. 2005). The more organic the lake bottom the greater the chances that the hypolimnion/sediment pore waters turn anoxic/corrosive (Dean 1999). Such a development might have influenced the cycling of carbonate and productivity limiting elements in Les Echets (Bernasconi et al. 1997), partly explaining the trends in the organic matter stable isotopes which became enriched at times of high lake productivity (Fig. 2). On the other hand, a lowering of the lake level or ventilation changes leading to enhanced oxygen availability in the water column (and therefore enhanced organic matter degradation) at the time of deposition of clayey gyttja silts could be an explanation for the moderate to high Ol observed in the minerogenic-rich sediments (Fig. 5B). 


\section{Palaeoenvironmental reconstruction and comparison with other records}

\section{Climate and environment at Les Echets between c. 46.1 and $36.1 \mathrm{kyr}$ BP}

Early to middle MIS 3 is characterized in Greenland ice cores (Dansgaard et al. 1993; Johnsen et al. 2001; NGRIP members 2004) and marine sediment records (Sánchez Goñi et al. 2002; Moreno et al. 2005; Roucoux et al. 2005) by several interstadial events (17-9), of which, DO 12 and 14 are of considerable length. DO 12 and 14 have also been the warmest intervals of MIS 3 and are clearly recognizable in pollen records from terrestrial sites (Allen et al. 1999; Tzedakis et al. 2004) and land-sea climate proxies in marine cores from Mediterranean Europe (Sánchez Goñi et al. 2002, 2008; Moreno et al. 2005; Roucoux et al. 2005).

The ages of $c .46 .1-36.1$ obtained for sediments between 30.06 and $27.48 \mathrm{~m}$ place this part of the Les Echets record in early to middle MIS 3 (Fig. 2). There are no indications of interstadial events in these sediments, and it is highly unlikely that there was no response of the Les Echets ecosystem to the interstadial conditions of early to middle MIS 3. Instead, the frequency of erosional contacts points to episodic sedimentation and/or sediment removal in this part of the sequence of Les Echets, distorting the age estimates and making palaeoenvironmental reconstructions and correlations difficult. The presence of sand layers in unit $\mathrm{H}$ at such a distance from the basin margin implies either very low water stands and littoral sedimentation or high-energy environments capable of transporting coarse particles to the middle of the lake. On the other hand, it is possible that the sandy layers represent low density sediment flows (turbidite layers) resulting from sediment re-suspension in the basin, although the particular grading specific to such deposits is not apparent for the sandy layers in unit $\mathrm{H}$. Taking also into account the depth of the sediment in the basin (c. 28-30 m) and the distance of the coring site to the basin margin (c. $1 \mathrm{~km})$, a good alternative explanation for the sedimentary gaps would be erosion by bottom/gravity currents or sediment sliding/slumping.

In accordance with lithostratigraphic observations (Fig. 2), the age model indicates the presence of several hiatuses in this part of the record, the largest at 28.1-27.9 m (c. 43.6-36.3 kyr BP) (Wohlfarth et al. 2008). The age estimates for this hiatus coincide in part with the time interval suggested for the $\mathrm{H} 4$ (Thouveny et al. 2000; Combourieu-Nebout et al. 2002; Sánchez Goñi et al. 2002; Moreno et al. 2004; Rasmussen \& Thomsen 2004). We speculate that the severe cold and arid conditions during H 4 over western Europe (Combourieu-Nebout et al. 2002; Sánchez Goñi et al. 2002; de Abreu et al. 2003; Genty et al. 2003; Moreno et al. 2004; Roucoux et al. 2005) led to dramatic changes in the hydrologic regime at Les Echets (changes observed also during other $\mathrm{H}$ events), triggering sediment re-suspension and/or erosion. Given the uncertainty of the age model for unit $\mathrm{H}$, it is also possible that the interval with very high OI values between 29.40 and $29.05 \mathrm{~m}$, dated to c. 45.7$45.0 \mathrm{kyr} \mathrm{BP}$, correlates with parts of Heinrich event $5(\mathrm{H} 5)$, which is dated to that age interval (Cortijo et al. 2000; Hemming 2004; Moreno et al. 2004; Rasmussen \& Thomsen 2004).

Pollen-stratigraphic data (de Beaulieu \& Reille 1984) indicate that sedimentation during MIS 5 at Les Echets has been continuous, but sediments of MIS 4 to early MIS 3 age are most likely disturbed/missing in the centre of the basin (Allen \& Huntley 2000; de Beaulieu et al. 2001; Guiter et al. 2003; Veres et al. 2007). It is 
possible that the coring location of EC1 was either periodically desiccated during MIS 4 to early MIS 3, or, more likely, had fluctuating water levels (Veres et al. 2007; Ampel et al. 2008). A combination of very dry conditions at Les Echets during MIS 4 (de Beaulieu \& Reille 1984) and low water levels during stadials and Heinrich events (Ampel et al. 2008) could therefore have triggered rapid and repeated migration of shorelines, resulting in gaps in sedimentation. Higher precipitation at the beginning of interstadial events could in turn have led to a rapid rise of the lake level and changes in the hydrodynamic properties causing erosion of underlying levels (Veres et al. 2007, 2008; Wohlfarth et al. 2008). Therefore, a combination of climate and internal basin dynamics is probably responsible for the unstable sedimentation conditions in the centre of the basin during this time interval, as evidence for early-middle MIS 3 interstadial events has been documented in the littoral core EC3 (see Veres et al. 2007, 2008 for details).

\section{Climate and environment at Les Echets between c. 36.1 and $15.0 \mathrm{kyr}$ BP}

The most intriguing attribute of this time period at Les Echets is the alternating deposition of silty gyttja layers rich in organic contents and separated by distinct minerogenic layers (Fig. 2). Apparently, the rise in organic content was very rapid and was followed by a phase during which productivity remained high for hundreds of years. Wohlfarth et al. (2008) showed that these lithological variations are the lacustrine sedimentary expression of DO interstadials and stadials from late MIS 3 and MIS 2.

The first of the lake organic productivity events in Les Echets (following the hiatus), occurred between c. 36.2 and $35.7 \mathrm{kyr}$ BP and its double-peak suggests that it most likely correlates with parts of DO interstadial 8 (Fig. 2). At about $35.7 \mathrm{kyr}$ BP, the lake entered a phase dominated by clastic sedimentation which lasted for about 400 years. The temperature rise and increased moisture availability leading into DO interstadial 7 at $35.3 \mathrm{kyr}$ BP corresponds to a shift towards higher productivity in the lake. The lake remained productive for several hundred years before the rapid shift to a new phase of predominantly clastic sedimentation. These conditions persisted for about 300 years (34.7-34.4 kyr BP), after which the productivity gradually increased in a saw-tooth manner, remained high for another 200 years and rapidly declined, reaching stadial levels at about $34.2 \mathrm{kyr}$ BP. The rise in lake productivity at $33.5 \mathrm{kyr}$ BP coincides with maximum temperatures at the start of DO interstadial 6 , during which the lake remained highly productive for about 600 years (33.5-32.9 kyr BP). A gradual and oscillatory decline in lake productivity occurred between 33.0 and $32.5 \mathrm{kyr} \mathrm{BP}$, before the lake entered a new phase of low productivity lasting until $32.1 \mathrm{kyr}$ BP. This cold phase most likely coincides with the coldest part of the stadial between DO interstadials 6 and 5 . A subsequent rise in productivity at $32.1 \mathrm{kyr}$ BP coincides with the onset of DO interstadial 5 (Figs 2, 3).

Between 30 and $22 \mathrm{kyr}$ BP the record shows only minor increases in organic productivity centred around 29.5 and $28.1 \mathrm{kyr}$ BP (Figs 2, 3), which indicates that general climatic conditions had become colder in the region than during the preceding intervals (Genty et al. 2003; Rousseau et al. 2007). The age model indicates that these minor productivity events might correlate with DO interstadials 3 and 4, which are considered relatively moist/warm events in other parts of Europe (Chondrogianni et al. 2004) and the North Atlantic (Weinelt et al. 2003). 
The organic matter deposited during the interstadial events at Les Echets consists of a mixture of algal and terrestrial components, suggesting that environmental conditions allowed for both high lake productivity and development of vegetation in the drainage area. The intervals dominated by minerogenic sedimentation represent periods of limited primary production and organic matter degradation, and reflect stadial conditions (Fig. 2). The trends in the geochemical proxies discussed in this article are closely replicated by shifts in the biogenic silica content, diatom communities dynamics (Ampel et al. 2008) and vegetation changes (Wohlfarth et al. 2008).

Pollen-stratigraphic records from lake sites in southern Europe (Allen et al. 1999; Tzedakis et al. 2004) and parallel investigations of land-sea climate proxies from marine cores obtained in the Mediterranean (Moreno et al. 2004, 2005) and on the Atlantic Margin of Western Europe (Sánchez Goñi et al. 2002, 2008; de Abreu et al. 2003; Roucoux et al. 2005) indicate a quasi synchronous response of vegetation to rapid climate variability for these regions. Variations in pollen composition, which could be directly correlated with isotopic and sea surface temperature estimates from the same samples, showed that vegetation changes were directly related to the succession of relatively wet/warm (interstadial) and cool/dry (stadial) conditions in the nearby Atlantic Ocean. While several periods of high primary productivity are seen at Les Echets between c. 36.2 and 28 kyr BP, only two interstadial events, Hengelo and Denekamp, have been recognized in pollen-stratigraphic records from central and northwest Europe for the same time interval (Behre 1989; Allen \& Huntley 2000; Caspers \& Freund 2001; Guiter et al. 2003; Müller et al. 2003; Preusser 2004). The high-resolution geochemical and chronological record for core EC1 indicates that these terrestrial interstadials were not individual events, but may contain several events with alternating interstadial and stadial conditions, partly explaining the discrepancies in the dating (Behre 1989; Caspers \& Freund 2001) and environmental reconstructions (Guiter et al. 2003) for these events.

Notably low organic contents between 31.7 and $30.9 \mathrm{kyr}(22.54-21.82 \mathrm{~m})$ point to an event when lake primary productivity was drastically reduced (Figs 2, 3). Although the timing of $\mathrm{H}$ events is difficult to constrain, and estimates of their strength and environmental impact largely differ from study to study (e.g. Hemming 2004; Roche et al. 2004), our age model suggests that this period of low productivity at Les Echets is the terrestrial/lacustrine equivalent of $\mathrm{H} 3$. Furthermore, the impact of $\mathrm{H} 2$ is recognizable in the interval with very low organic content between $c .26 .4$ and $22.0 \mathrm{kyr}$ BP (14.88-16.18 m), just before the rise in productivity and carbonate content at c. 22-20.0 kyr BP (Unit D; Figs 2, 3). Proxy records from Iberia and the North Atlantic also document a moist and warm interval between 23 and $19 \mathrm{kyr}$ BP (Bard et al. 2000; Roucoux et al. 2005), and its presence at Les Echets indicates that this moist/warm interval, most likely corresponding to DO 2, was of regional importance (Rousseau et al. 2007).

Palynological records from marine cores off the coast of lberia (Sánchez Goñi et al. 2002; Moreno et al. 2005; Roucoux et al. 2005), as well as loess records from continental Europe (Hatté \& Guiot 2005; Rousseau et al. 2007), indicate that, in general, $\mathrm{H}$ events 3 and 2 led to a drastic reduction in forest cover as a response to aridity and cold air temperatures. Influxes of Polar waters into the Mediterranean further hampered productivity and caused large decreases in sea surface 
temperature (Moreno et al. 2004; Sierro et al. 2005). In our case, H 3 and 2 are associated with a strong reduction in aquatic productivity, minerogenic deposition as well as enhanced organic matter mineralization (Figs 2, 3).

The period between $\mathrm{H} 3$ and $\mathrm{H} 2$ is interpreted in some records as the coldest of MIS 3 and 2 (Roucoux et al. 2005) with temperatures and moisture gradually decreasing as full glacial conditions approached. The long period with very low values for organic productivity indicators after c. $28 \mathrm{kyr} B P$ (in units $D$ to B) indicates that climate was relatively stable, dry and cold (e.g. Hatté \& Guiot 2005) with low aquatic productivity at Les Echets (Ampel et al. 2008). During this time, the nearby alpine glaciers expanded to within 10-15 km of the site (de Beaulieu \& Reille 1984). Extensive meltwater deposits in front of the glacier lobes would also have been prone to aeolian deflation. Increased influx of aeolian dust from both local and distal sources may also partly explain the relatively high accumulation rates observed at Les Echets at times approaching full glacial conditions (de Beaulieu \& Reille 1984; Wohlfarth et al. 2008). It is possible, therefore, that the high minerogenic input to the lake either diluted the organic fraction, or, perhaps more likely, that a high percentage of mineral particles in the water column during a cold climate inhibited primary productivity (Ampel et al. 2008).

Apart from showing that crucial palaeoenvironmental information can be obtained by studying the organic fraction within lacustrine sediments, the results of this study also demonstrate that the site of Les Echets could represent a link between sites in northern central Europe and the Mediterranean region. In the context of rapid climate variability, Les Echets can provide a basis for the reinvestigation of northern central European records, which, from a vegetation point of view more closely parallel Les Echets than records from Mediterranean Europe (Behre 1989; Allen \& Huntley 2000).

\section{Synthesis and conclusions}

We have reconstructed past lake organic productivity and catchment erosion based on a sedimentological and geochemical investigation of a $30 \mathrm{~m}$ long core from Les Echets spanning the time period c. 46 to $15 \mathrm{kyr}$ BP. This reconstruction indicates cyclic alternation of different depositional environments and productivity levels, which seems to reflect the climatic fluctuations that occurred during late MIS 3 and 2, namely $\mathrm{DO}$ cycles and $\mathrm{H}$ events. Each of the productivity phases in Les Echets relates to regional temperature and humidity changes, which triggered internal basin dynamics such as lake level variations, changes in organic matter inputs and preservation state, erosive events and the ultimate rapid in-filling of the lake. The carbon cycling in Les Echets is primarily the result of increased phytoplankton production during favourable climatic conditions that correlate to DO interstadials 8-2 (Fig. 2). The increases in organic carbon are paralleled by enriched $\delta^{13} C_{\text {org }}$ and $\delta^{15} \mathrm{~N}_{\text {tot }}$, and high hydrogen index values indicating dominance of aquatic primary production during the productive intervals. Variations in organic matter stable isotopes seem to reflect changes/limitations in the productive limiting elements and a mixture of organic matter sources, with periods of abundant contribution of aquatic primary producers, mixed with different types of terrestrial and soil-derived organic components in different oxidation states. 
Good preservation of organic matter during the productive events is inferred from trends in the hydrogen and oxygen indices, while minerogenic-rich sediments deposited during DO stadials show moderate organic matter degradation. On the contrary, intense degradation of organic matter, extremely limited primary productivity and high clastic input to the lake occurred at Les Echets during times of large icerafted detritus and meltwater discharges in the Atlantic Ocean, i.e. $\mathrm{H}$ events 2-5. The dry and harsh environmental conditions reconstructed for western Europe during $\mathrm{H}$ events were most likely associated with lake level variations at Les Echets, partly explaining the occurrence of a hiatus in our record corresponding in part to $\mathrm{H} 4$.

In general, the abrupt and high-amplitude oscillations at Les Echets correlate well with the timing and amplitude of climatic events recorded in the Greenland ice-core records (see Wohlfarth et al. 2008). Overall, high sedimentation rates allowed for high temporal resolution for constraining the timing of oscillations in lake productivity in Les Echets. Palaeoenvironmental proxies at Les Echets vary in concert during MIS 3 and 2, and these new geochemical data highlight the palaeoclimatic potential of this site in not only linking the Mediterranean records to the northern European records, but also for increasing our understanding of how lake systems respond to rapid climate change in general.

Acknowledgements. - We owe special thanks to Heike Siegmund (IGG) for help with organic matter elemental and stable isotopes analyses. Gunhild Rosqvist and Angelica Feurdean kindly commented on earlier versions of the article. Comments by Denis-Didier Rousseau and an anonymous reviewer greatly improved the manuscript. Part of the analytical work was financially supported through a scholarship to Daniel Veres from the Swedish Society for Anthropology and Geography. This is a contribution to the ESF EuroCores on EuroCLIMATE project RESOLUTION.

\section{References}

Allen, J. R. M. \& Huntley, B. 2000: Weichselian palynological records from southern Europe: correlation and chronology. Quaternary International 73-74, 111-125.

Allen, J. R. M., Brandt, U., Brauer, A., Hubberten, H.-W., Huntley, B., Keller, J., Kraml, M., Mackensen, A., Mingram, J., Negendank, J. F. W., Nowaczyk, N. R., Oberhansli, H., Watts, W. A., Wulf, S. \& Zolitschka, B. 1999: Rapid environmental changes in southern Europe during the last glacial period. Nature 400, 740-743. 
Ampel, L., Wohlfarth, B., Risberg, J. \& Veres, D. 2008: Paleolimnological response to millennial and centennial scale climate variability during MIS 3 and 2 as suggested by the diatom record in Les Echets, France. Quaternary Science Reviews

Andersen, K. K., Svensson, A., Johnsen, S. J., Rasmussen, S. O., Bigler, M., Röthlisberger, R., Ruth, U., Siggaard-Andersen, M.-L., Steffensen, J. P., DahlJensen, D., Vinther, B. M. \& Clausen, H. B. 2006: The Greenland Ice Core chronology 2005, 15-42 ka. Part 1: Constructing the time scale. Quaternary Science Reviews 25, 3246-3257.

Ariztegui, D., Chondrogianni, C., Lami, A., Guilizzoni, P. \& Lafargue, E. 2001: Lacustrine organic matter and the Holocene paleoenvironmental record of Lake Albano (central Italy). Journal of Paleolimnology 26, 283-292.

Bard, E., Rostek, F., Turon, J.-L. \& Gendreau, S. 2000: Hydrological impact of Heinrich Events in the subtropical Northeast Atlantic. Science 289, 1321-1324.

Behre, K.-E. 1989: Biostratigraphy of the last glacial period in Europe. Quaternary Science Reviews 8, 25-44.

Bernasconi, S. M., Barbieri, A. \& Simona, M. 1997: Carbon and nitrogen isotope variations in sedimenting organic matter in Lake Lugano. Limnology Oceanography 42, 1755-1765.

Bertrand, P. \& Lallier-Vergès, E. 1993: Past sedimentary organic matter accumulation and degradation controlled by productivity. Nature $364,786-788$.

Blaauw, M. \& Christen, J. A. 2005: Radiocarbon peat chronologies and environmental change. Applied Statistics 54, 805-816.

Bond, G., Hartmut, H., Broecker, W., Labeyrie, L., McManus, J., Andrews, J., Huon, S., Jantschik, R., Clasen, S., Simet, C., Tedesco, K., Klas, M., Bonani, G. \& Ivy, S. 1992: Evidence for massive discharges of icebergs into the North Atlantic Ocean during the last glacial period. Nature $360,245-249$. 
Brauer, A., Mingram, J., Frank, U., Günter, C., Schettler, G., Wulf, S., Zolitschka, B. \& Negendank, J. F. W. 2000: Abrupt environmental oscillations during the Early Weichselian recorded at Lago Grande di Monticchio, southern Italy. Quaternary International 73/74, 79-90.

Broecker, W., Bond, G., Klas, M., Clark, E. \& McManus, J. 1992: Origin of the northern Atlantic's Heinrich events. Climate Dynamics 6, 265-273.

Caspers, G. \& Freund, H. 2001: Vegetation and climate in the Early- and PleniWeichselian in northern Central Europe. Journal of Quaternary Science 21, 31-48.

Chondrogianni, C., Ariztegui, D., Rolph, T., Juggins, S., Shemesh, A., Rietti-Shati, M., Niessen, F., Guilizzoni, P., Lami, A., McKenzie, J. A. \& Oldfield, F. 2004: Millennial to interannual climate variability in the Mediterranean during the Last Glacial Maximum. Quaternary International 122, 31-41.

Clark, P. U., Pisias, N. G., Stocker, T. F. \& Weaver, A. J. 2002: The role of the thermohaline circulation in abrupt climate change. Nature 415, 863-869.

Combourieu-Nebout, N., Turon, J. L., Zahn, R., Capotondi, L., Londeix, L. \& Pahnke, K. 2002: Enhanced aridity and atmospheric high-pressure stability over the western Mediterranean during the North Atlantic cold events of the past 50 k.y. Geology 30, 863-866.

Cortijo, E., Labeyrie, L., Elliot, M., Balbon, E. \& Tisnerat, N. 2000: Rapid climatic variability of the North Atlantic Ocean and global climate: a focus of the IMAGES program. Quaternary Science Reviews 19, 227-241.

Dansgaard, W., Johnsen, S. J., Clausen, H. B., Dahl-Jensen, D., Gundestrup, N. S., Hammer, C. U., Hvidberg, C. S., Steffensen, J. P., Sveinbjörnsdottir, A. E., Jouzel, J. \& Bond, G. 1993: Evidence for general instability of past climate from a 250-kyr icecore record. Nature 364, 218-220. 
Dean, W. E. 1999: The carbon cycle and biogeochemical dynamics in lake sediments. Journal of Paleolimnology 21, 375-393.

Dean, W. E. 2006: Characterization of organic matter in lake sediments from Minnesota and Yellowstone National Park. U.S. Geological Survey Open-File Report 2006-1053, 40 pp.

de Abreu, L., Shackleton, N. J., Schönfeld, J., Hall, M. \& Chapman, M. R. 2003: Millennial-scale oceanic climate variability off the Western Iberian margin during the last two glacial periods. Marine Geology 196, 1-20.

de Beaulieu, J.-L. \& Reille, M. 1984: A long Upper Pleistocene pollen record from Les Echets, near Lyon, France. Boreas 13, 111-132.

de Beaulieu, J.-L., Andrieu-Ponel, V., Reille, M., Grüger, E., Tzedakis, C. \& Svobodova, H. 2001: An attempt at correlation between the Velay pollen sequence and the Middle Pleistocene stratigraphy from central Europe. Quaternary Science Reviews 20, 1593-1602.

Engels, S., Bohncke, S., Heiri, O., Shaber, K. \& Sirocko, F. 2008: The lacustrine sediment record of Oberwinkler Maar (Eifel, Germany): Chironomid and macroremain-based inferences of environmental changes during Oxygen Isotope Stage 3. Boreas 37, 414-425.

Eusterhues, K., Heinrichs, H. \& Schneider, J. 2005: Geochemical response on redox fluctuations in Holocene lake sediments, Lake Steisslingen, Southern Germany. Chemical Geology 222, 1-22.

Ficken, K. J., Street-Perrott, F. A., Perrott, R. A., Swain, D. L., Olago, D. O. \& Eglinton, G. 1998: Glacial/interglacial variations in carbon cycling revealed by molecular and isotope stratigraphy of Lake Nkunga, Mt. Kenya, East Africa. Organic Geochemistry 29, 1701-1719. 
Filippi, M. L. \& Talbot, M. R. 2005: The palaeolimnology of northern Lake Malawi over the last $25 \mathrm{ka}$ based upon the elemental and stable isotopic composition of sedimentary organic matter. Quaternary Science Reviews 24, 1303-1328.

Freudenthal, T., Wagner, T., Wenzhöfer, F., Zabel, M. \& Wefer, G. 2001: Early diagenesis of organic matter from sediments of the eastern subtropical Atlantic: Evidence from stable nitrogen and carbon isotopes. Geochimica et Cosmochimica Acta 65, 1795-1808.

Fuhrmann, A., Mingram, J., Lücke, A., Lu, H., Horsfield, B., Liu, J., Negendank, J. W. F., Schleser, G. H. \& Wilkes, H. 2003: Variations in organic matter composition in sediments from Lake Huguang Maar (Huguangyan), south China during the last 68 ka: implications for environmental and climatic change. Organic Geochemistry 34 , 1497-1515.

Genty, D., Blamart, D., Ouahdi, R., Gilmour, M., Baker, A., Jouzel, J. \& Van-Exter, S. 2003: Precise dating of Dansgaard-Oeschger climate oscillations in western Europe from stalagmite data. Nature 421, 833-837.

Grimm, E. C., Watts, W. A., Jacobson Jr, G. L., Hansen, B. C. S., Almquist, H. R. \& Dieffenbacher-Krall, A. C. 2006: Evidence for warm wet Heinrich events in Florida. Quaternary Science Reviews 25, 2197-2211.

Guiot, J., Pons, A., de Beaulieu, J.-L. \& Reille, M. 1989: A 140,000-year continental climate reconstruction from two European pollen records. Nature 338, 309-313.

Guiter, F., Andrieu-Ponel, V., de Beaulieu, J.-L., Cheddadi, R., Calvez, M., Ponel, P., Reille, M., Keller, T. \& Goeury, C. 2003: The last climatic cycles in Western Europe: A comparison between long continuous lacustrine sequences from France and other terrestrial records. Quaternary International 111, 59-74.

Hatté, C. \& Guiot, J. 2005: Palaeoprecipitation reconstruction by inverse modelling using the isotopic signal of loess organic matter: Application to the Nußloch loess sequence (Rhine Valley, Germany). Climate Dynamics 25, 315-327. 
Heiri, O., Lotter, A. F. \& Lemcke, G. 2001: Loss on ignition as a method for estimating organic and carbonate content in sediments: Reproducibility and comparability of results. Journal of Paleolimnology 25, 101-110.

Helmens, K. F., Räsänen, M. E., Johansson, P. W., Jungner, H. \& Korjonen, K. 2000: The Last Interglacial-Glacial cycle in NE Fennoscandia: A nearly continuous record from Sokli (Finnish Lapland). Quaternary Science Reviews 19, 1605-1623.

Hemming, S. R. 2004: Heinrich events: Massive late Pleistocene detritus layers of the North Atlantic and their global climate imprint. Review of Geophysics $\mathbf{4 2}$

Jacob, J., Disnar, J.-R., Boussafir, M., Sifeddine, A., Turcq, B. \& Spadano Albuquerque, A. L. 2004: Major environmental changes recorded by lacustrine sedimentary organic matter since the last glacial maximum near the equator (Lagoa do Caçó, NE Brazil). Palaeogeography, Palaeoclimatology, Palaeoecology 205, 183197

Johnsen, S. J., Dahl-Jensen, D., Gundestrup, N., Steffensen, J. P., Clausen, H. B., Miller, H., Mason-Delmotte, V., Sveinbjörndottir, A. E. \& White, J. 2001: Oxygen isotope and palaeotemperature records from six Greenland ice-core stations: Camp Century, Dye-3, GRIP, GISP2, Renland and NorthGRIP. Journal of Quaternary Science 16, 299-307.

Lafargue, E., Marquis, F. \& Pillot, D. 1998: Rock-Eval 6 applications in hydrocarbon exploration, production, and soil contamination studies. Revue de l'Institut Français du Pétrole 53, 421-437.

Lallier-Vergès, E., Sifeddine, A., de Beaulieu, J.-L., Reille, M., Tribovillard, N., Bertrand, P., Mongenot, T., Thouveny, N., Disnar, J.-R. \& Guillet, B. 1993: Sensibilité de la sédimentation organique aux variations climatiques du Tardi-Würm de I'Holocène; le lac du Bouchet (Haute-Loire, France). Bulletin de la Société Géologique de France 164, 661-673. 
Lehmann, M. F., Bernasconi, S., Barbieri, A. \& McKenzie, J. A. 2002: Preservation of organic matter and alteration of its carbon and nitrogen isotope composition during simulated and in situ early sedimentary diagenesis. Geochimica et Cosmochimica Acta 66, 3573-3584.

Leng, M. J., Lamb, A. L., Marshall, J. D., Wolfe, B. B., Jones, M. D., Holmes, J. A. \& Arrowsmith, C. 2005: Isotopes in lake sediments. In Leng, M. J. (ed.): Isotopes in Palaeoenvironmental Research, 147-184. Springer, Dordrecht.

Lüniger, G. \& Schwark, L. 2002: Characterization of sedimentary organic matter by bulk and molecular geochemical proxies: An example from Oligocene maar-type Lake Enspel, Germany. Sedimentary Geology 148, 275-288.

Meyers, P. A. 1997: Organic geochemical proxies of paleoceanographic, paleolimnologic, and paleoclimatic processes. Organic Geochemistry 27, 213-250.

Meyers, P. A. 2003: Applications of organic geochemistry to paleolimnological reconstructions: A summary of examples from the Laurentian Great Lakes. Organic Geochemistry 34, 261-289.

Meyers, P. A. \& Lallier-Vergès, E. 1999: Lacustrine sedimentary organic matter records of Late Quaternary paleoclimates. Journal of Paleolimnology 21, 345-372.

Meyers, P. A. \& Teranes, J. L. 2001: Sediment organic matter. In Last, W. M. \& Smol, J. P. (eds.): Tracking Environmental Change Using Lake Sediments, vol. 2, Physical and Geochemical Methods, 239-269. Kluwer Academic Publishers, Dordrecht.

Moreno, A., Cacho, I., Canals, M., Grimalt, J. O., Sánchez-Goñi, M. F., Shackleton, N. \& Sierro, F. J. 2005: Links between marine and atmospheric processes oscillating on a millennial time-scale. A multi-proxy study of the last 50,000 yr from the Alboran Sea (Western Mediterranean Sea). Quaternary Science Reviews 24, 1623-1636.

Moreno, A., Cacho, I., Canals, M., Grimalt, J. O. \& Sanchez-Vidal, A. 2004:

Millennial-scale variability in the productivity signal from the Alboran Sea record, 
Western Mediterranean Sea. Palaeogeography, Palaeoclimatology, Palaeoecology 211, 205-219.

Müller, U. C., Pross, J. \& Bibus, E. 2003: Vegetation response to rapid climate change in central Europe during the past 140,000 yr based on evidence from the Füramoos pollen record. Quaternary Research 59, 235-245.

NGRIP members 2004: High-resolution record of Northern Hemisphere climate extending into the last interglacial period. Nature 431, 37-42.

Patience, A. J., Lallier-Vergès, E., Albéric, P., Desprairies, A. \& Tribovillard, N. 1996: Relationships between organo-mineral supply and early diagenesis in the lacustrine environment: A study of surficial sediments from the Lac du Bouchet (Haute Loire, France). Quaternary Science Reviews 15, 213-221.

Preusser, F. 2003: IRSL dating of K-rich feldspar using SAR protocol: Comparison with independent age control. Ancient TL 21, 17-23.

Preusser, F. 2004: Towards a chronology of the Late Pleistocene in the northern Alpine Foreland. Boreas 33, 195-210.

Rasmussen, T. L. \& Thomsen, E. 2004: The role of the North Atlantic Drift in the millennial timescale glacial climate fluctuations. Palaeogeography, Palaeoclimatology, Palaeoecology 210, 101-116.

Roche, D., Paillard, D. \& Cortijo, E. 2004: Constraints on the duration and freshwater release of Heinrich event 4 through isotope modeling. Nature 432, 379-382.

Roucoux, K. H., de Abreu, L., Shackleton, N. J. \& Tzedakis, P. C. 2005: The response of NW Iberian vegetation to North Atlantic climate oscillations during the last 65 kyr. Quaternary Science Reviews 24, 1637-1653. 
Rousseau, D. D., Sima, A., Antoine, P., Hatté, C., Lang, A. \& Zöller, L. 2007: Link between European and North Atlantic abrupt climate changes over the last glaciation. Geophysical Research Letters 34

Sánchez Goñi, M. F., Cacho, I., Turon, J.-L., Guiot, J., Sierro, F. J., Peypouquet, J.P., Grimalt, J. O. \& Shackleton, N. J. 2002: Synchroneity between marine and terrestrial responses to millennial scale climatic variability during the last glacial period in the Mediterranean region. Climate Dynamics 19, 95-105

Sánchez Goñi, M. F., Landais, A., Fletcher, W. J., Naughton, F., Desprat, S. \& Duprat, J. 2008: Contrasting impacts of Dansgaard - Oeschger events over a western European latitudinal transect modulated by orbital parameters. Quaternary Science Reviews 27, 1136-1141.

Sierro, F. J., Hodell, D. A., Curtis, J. H., Flores, J. A., Reguera, I., ColmeneroHidalgo, E., Bárcena, M. A., Grimalt, J. O., Cacho, I., Frigola, J. \& Canals, M. 2005: Impact of iceberg melting on Mediterranean thermohaline circulation during Heinrich events. Paleoceanography 20,

Sifeddine, A., Bertrand, P., Lallier-Vergès, E. \& Patience, A. J. 1996: Lacustrine organic fluxes and palaeoclimatic variations during the last $15 \mathrm{ka}$ : Lac du Bouchet (Massif Central, France). Quaternary Science Review 15, 203-211.

Sirocko, F., Seelos, K., Schaber, K., Rein, B., Dreher, F., Diehl, M., Lehne, R., Jäger, K., Krbetschek, M. \& Degering, D. 2005: A late Eemian aridity pulse in central Europe during the last glacial inception. Nature 436, 833-836.

Street-Perrott, F. A., Ficken, K. J., Huang, Y. \& Eglinton, G. 2004: Late Quaternary changes in carbon cycling on Mt. Kenya, East Africa: An overview of the $\delta^{13} \mathrm{C}$ record in lacustrine organic matter. Quaternary Science Reviews 23, 861-879.

Svensson, A., Andersen, K. K., Bigler, M., Clausen, H. B., Dahl-Jensen, D., Davies, S. M., Johnsen, S. J., Muscheler, R., Parrenin, F., Rasmussen, S. O., Röthlisberger, 
R., Seierstad, I., Steffensen, J. P. \& Vinther, B. M. 2008: A 60000 year Greenland stratigraphic ice core chronology. Climate of the Past 4, 47-57

Talbot, M. R. 2001: Nitrogen isotopes in paleolimnology. In Last, W. M. \& Smol, J. P. (eds.): Tracking Environmental Change Using Lake Sediments, vol. 2, Physical and Geochemical Methods, 401-439. Kluwer Academic Publishers, Dordrecht.

Talbot, M. R. \& Lærdal, T. 2000: The Late Pleistocene-Holocene palaeolimnology of Lake Victoria, East Africa, based upon elemental and isotopic analyses of sedimentary organic matter. Journal of Paleolimnology 23, 141-164.

Talbot, M. R. \& Livingstone, D. A. 1989: Hydrogen Index and carbon isotopes of lacustrine organic matter as lake level indicators. Palaeogeography, Palaeoclimatology, Palaeoecology 70, 121-137.

Thouveny, N., Moreno, E., Delanghe, D., Candon, L., Lancelot, Y. \& Shackleton, N. J. 2000: Rock magnetic detection of distal ice-rafted debris: Clue for the identification of Heinrich layers on the Portuguese margin. Earth and Planetary Science Letters 180, 61-75.

Tzedakis, P. C., Frogley, M. R., Lawson, I. T., Preece, R. C., Cacho, I. \& de Abreu, L. 2004: Ecological thresholds and patterns of millennial-scale climate variability: The response of vegetation in Greece during the last glacial period. Geology 32, 109112.

Veres, D., Davies, S. M., Wohlfarth, B., Preusser, F., Wastegård, S., Ampel, L., Hormes, A., Possnert, G., Raynal, J.-P. \& Vernet, G. 2008: Age, origin and significance of a new middle MIS 3 tephra horizon identified within a long-core sequence from Les Echets, France. Boreas 37, 434-443.

Veres, D., Wohlfarth, B., Andrieu-Ponel, V., Björck, S., de Beaulieu, J.-L., Digerfeldt, G., Ponel, P., Ampel, L., Davies, S., Gandouin, E. \& Belmecheri, S. 2007: The lithostratigraphy of the Les Echets basin, France: Tentative correlation between cores. Boreas 36, 326-340. 
Voelker, A. H. L.Workshop Participants. 2002: Global distribution of centennial-scale records for Marine Isotope Stage (MIS) 3: A database. Quaternary Science Reviews 21, 1185-1212.

Weinelt, M., Vogelsang, E., Kucera, M., Pflaumann, U., Sarnthein, M., Voelker, A., Erlenkeuser, H. \& Malmgren, B. A. 2003: Variability of North Atlantic heat transfer during MIS 2. Paleoceanography 18

Wilkes, H., Ramrath, A. \& Negendank, J. F. 1999: Organic geochemical evidence for environmental changes since 34,000 yrs BP from Lago di Mezzano, central Italy. Journal of Paleolimnology 22, 349-365.

Wohlfarth, B., Veres, D., Ampel, L., Lacourse, T., Blaauw, M., Preusser, F., AndrieuPonel, V., Kéravis, D., Lallier-Vergès, E., Björck, S., Davies, S. M., de Beaulieu, J.-L., Risberg, J., Hormes, A., Kasper, H. U., Possnert, G., Reille, M., Thouveny, N. \& Zander, A. 2008: Rapid ecosystem response to abrupt climate changes during the last glacial period in western Europe, 40-16 ka. Geology 36, 407-410

Woillard, G. M. \& Mook, W. G. 1982: Carbon-14 dates at Grande Pile: Correlation of land and sea chronologies. Science 215, 159-161.

Zolitschka, B. \& Negendank, J. F. W. 1996: Sedimentology, dating and palaeoclimatic interpretation of a 76.3 ka record from Lago Grande di Monticchio, southern Italy. Quaternary Science Reviews 15, 101-112 


\section{Figures}

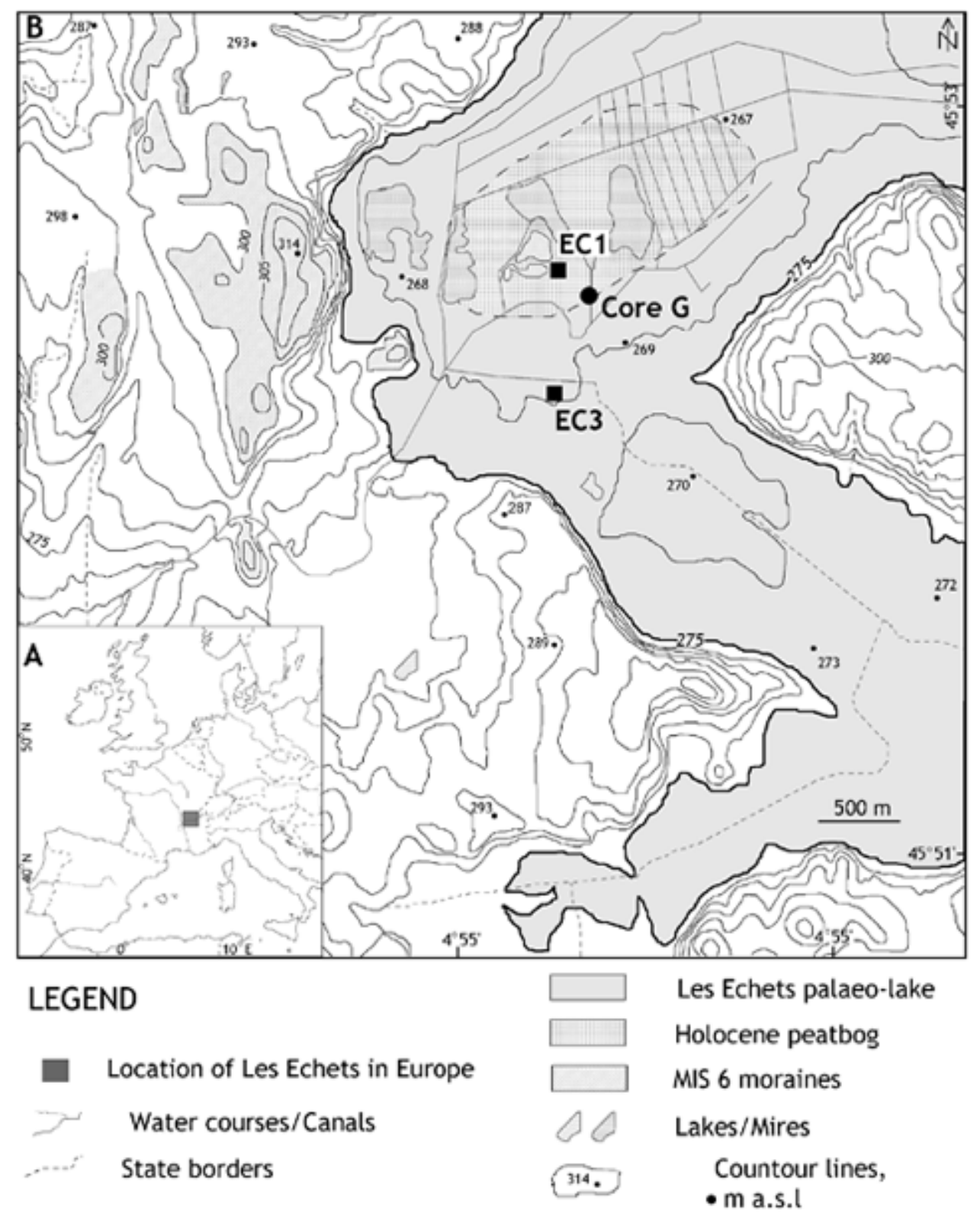

Fig. 1. A. Location of Les Echets palaeo-lake in Europe. B. Les Echets palaeobasin, with the location of the coring sites marked by rectangles (EC1 and EC3) and circle (core G; de Beaulieu \& Reille 1984). 


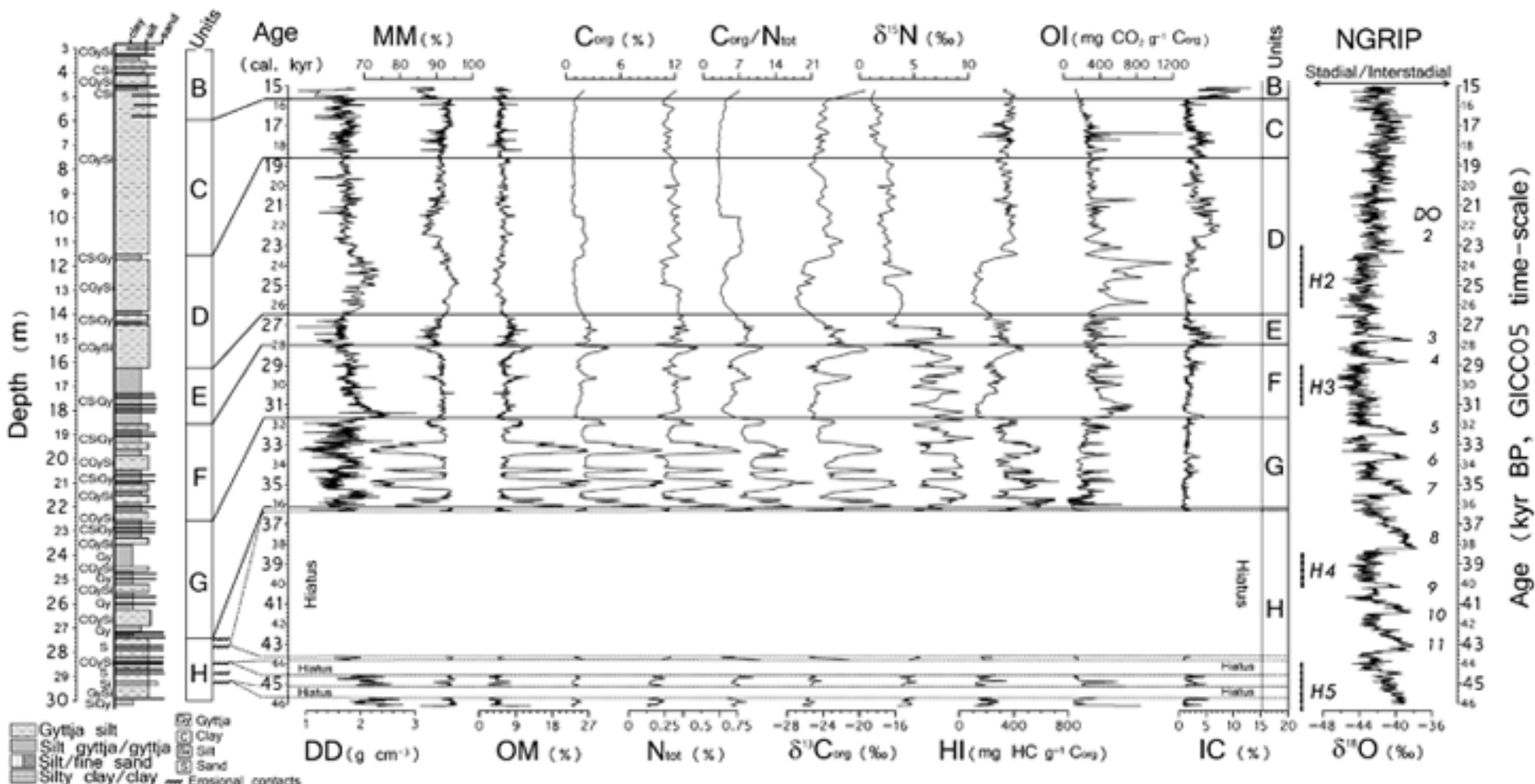

Fig. 2. Lithostratigraphy (on a depth scale) and vertical profiles of minerogenic matter content (MM), dry density (DD), organic matter content $(\mathrm{OM})$, organic carbon content $\left(\mathrm{C}_{\text {org }}\right)$, total nitrogen content $\left(\mathrm{N}_{\text {tot }}\right), \mathrm{C}_{\text {org }} / \mathrm{N}_{\text {tot }}$ ratio, organic matter carbon $\left(\delta^{13} \mathrm{C}_{\text {org }}\right)$ and nitrogen $\left(\delta^{15} \mathrm{~N}_{\text {tot }}\right)$ stable isotopes, hydrogen (HI) and oxygen (OI) indices and inorganic carbon content (IC) plotted on an age scale. The horizontal lines delimit stratigraphic units. The stippled vertical lines delimit the calibrated age ranges for Heinrich $(\mathrm{H})$ events 5, 4, 3 and 2 (Bard et al. 2000 ; Thouveny et al. 2000; Sánchez Goñi et al. 2002; de Abreu et al. 2003; Hemming 2004). The $\delta^{18} \mathrm{O}$ curve and GICC05 time scale for the NGRIP ice core follow Andersen et al. (2006) and Svensson et al. (2008). DO refer to Dansgaard-Oeschger interstadials 

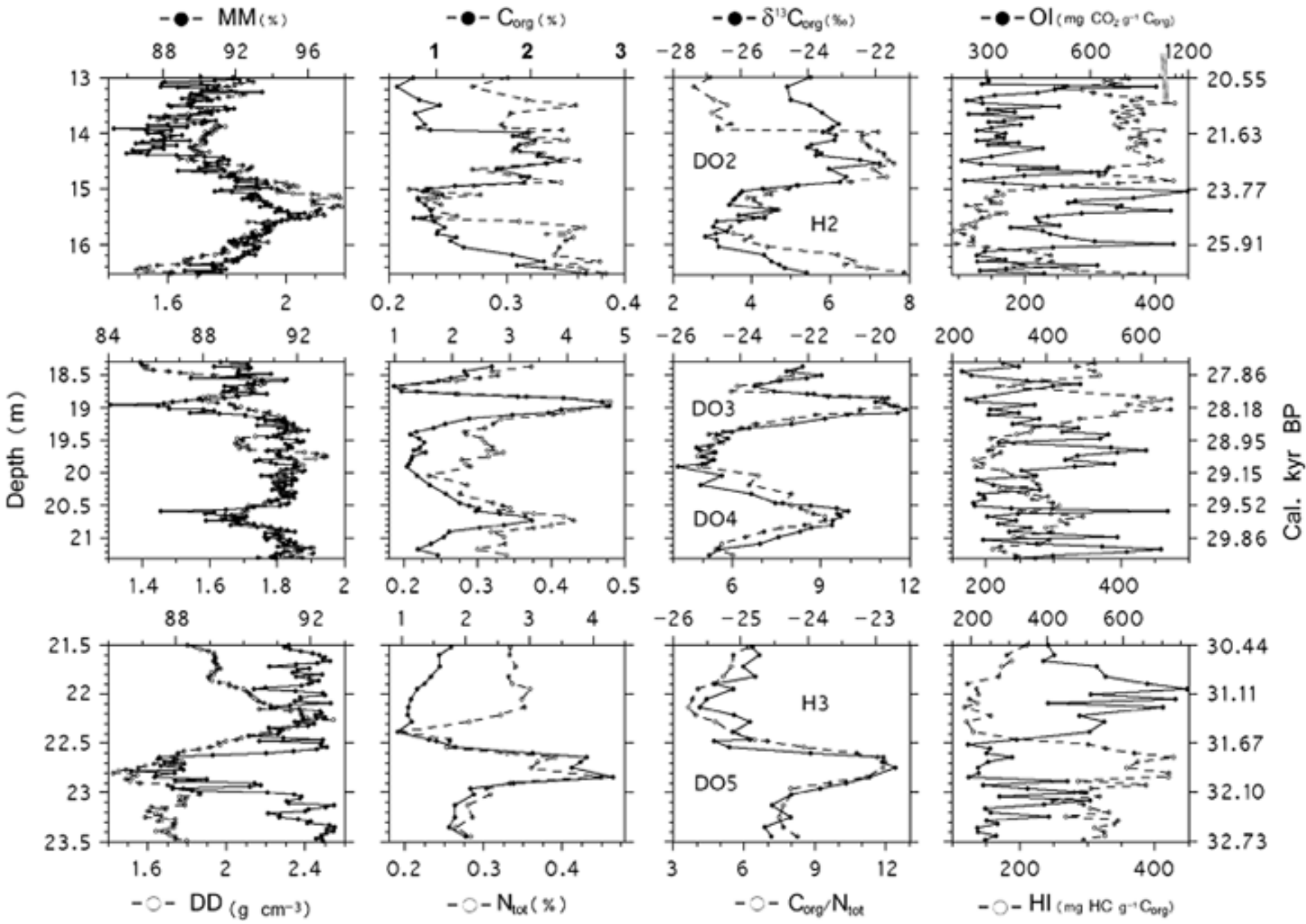

Fig. 3. Detailed plots over selected intervals in core EC1. The age estimates presented in the right-hand scale are exclusively for the major ticks in the depth scale, without linear interpolation between the plotted ages. 

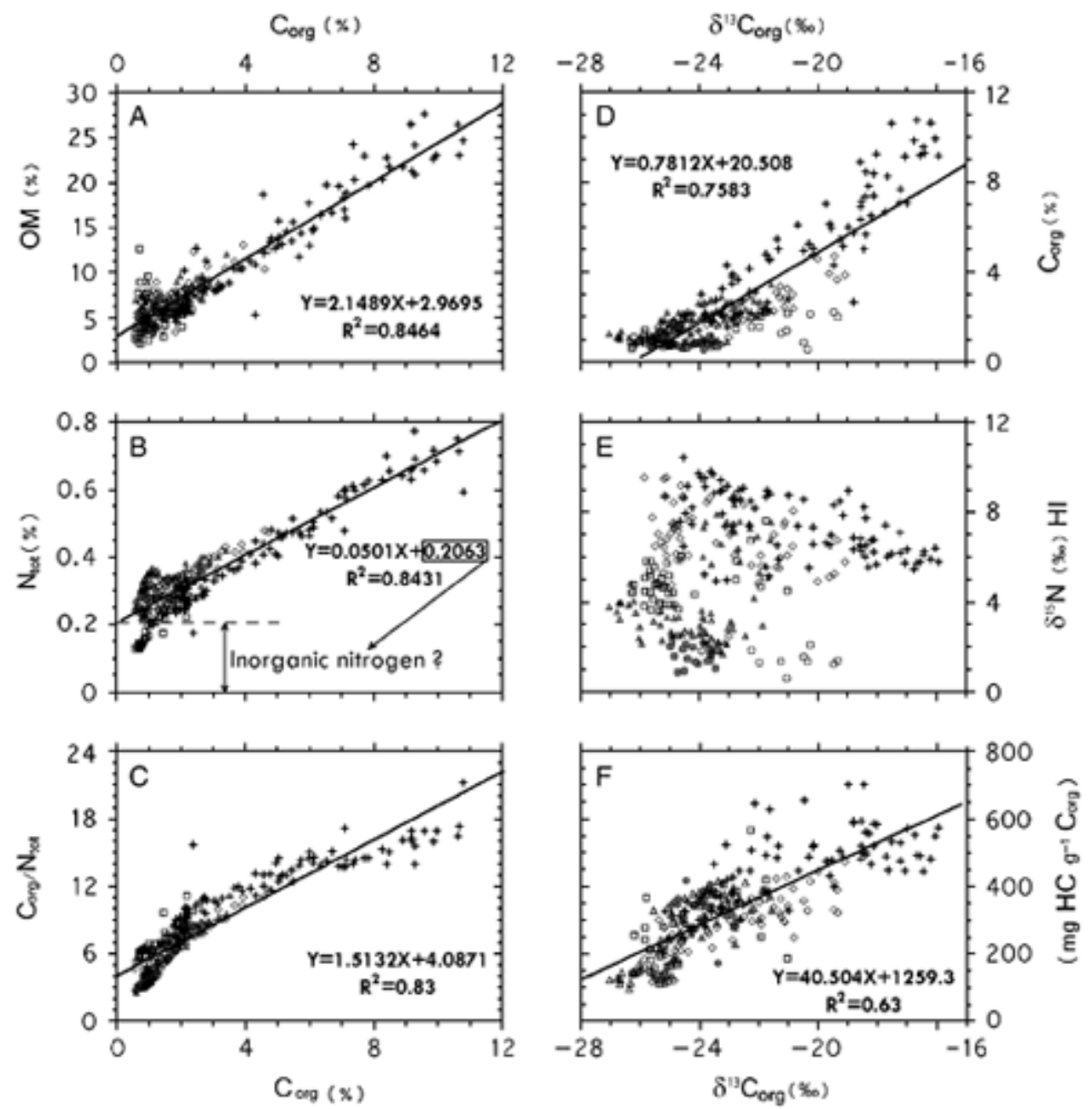

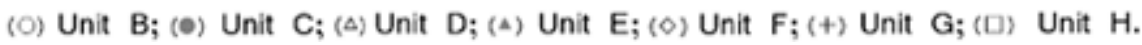

Fig. 4. Cross-plots of (A) organic carbon $\left(\mathrm{C}_{\text {org }}\right)$ and organic matter $(\mathrm{OM})$; (B) organic carbon $\left(\mathrm{C}_{\text {org }}\right)$ and total nitrogen $\left(\mathrm{N}_{\text {tot }}\right) ;(\mathrm{C})$ organic carbon $\left(\mathrm{C}_{\text {org }}\right)$ and $\mathrm{C}_{\text {org }} / \mathrm{N}_{\text {tot }}$ ratio; (D) $\delta^{13} \mathrm{C}_{\text {org }}$ and organic carbon $\left(\mathrm{C}_{\text {org }}\right)$; (E) $\delta^{13} \mathrm{C}_{\text {org }}$ and $\delta^{15} \mathrm{~N}_{\text {tot }}$ and $(\mathrm{F}) \delta^{13} \mathrm{C}_{\text {org }}$ and hydrogen index (HI). 

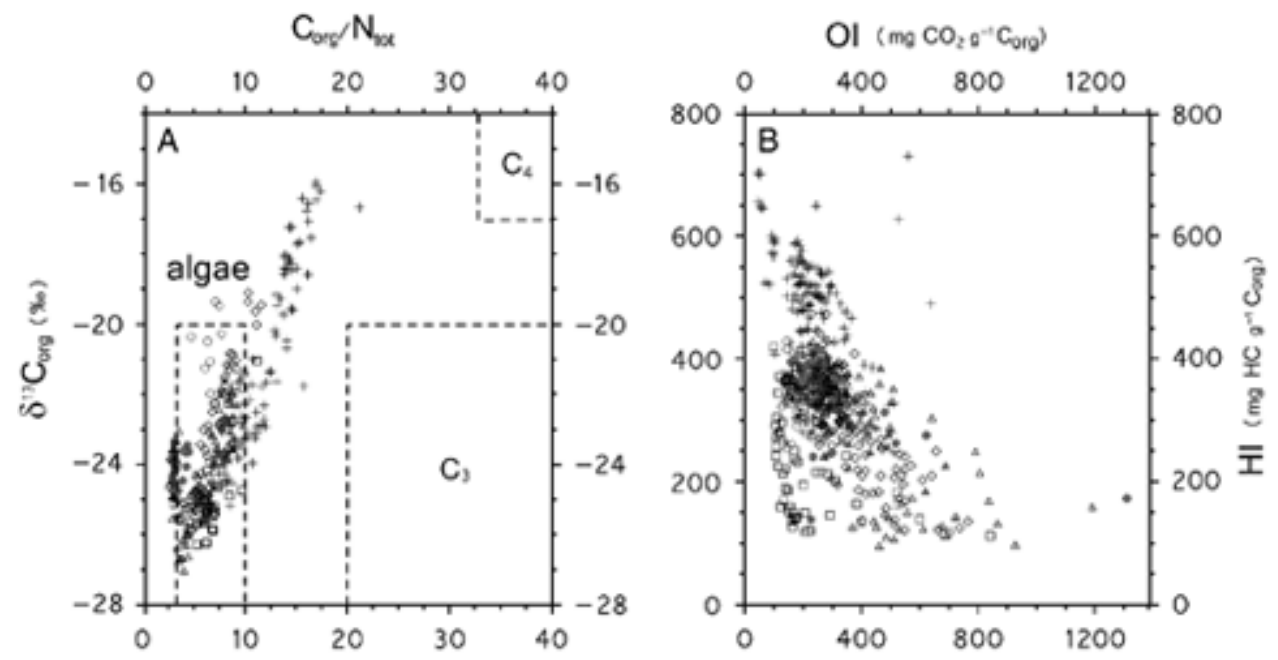

(0) Unit $\mathrm{B} ;(\bullet)$ Unit $\mathrm{C} ;(\Delta)$ Unit $\mathrm{D} ;(\Delta)$ Unit $\mathrm{E} ;(0)$ Unit $\mathrm{F} ;(+)$ Unit $\mathrm{G} ;(a)$ Unit $\mathrm{H}$.

Fig. 5. A. Cross-plots of $\mathrm{C}_{\text {org }} / \mathrm{N}_{\text {tot }}$ and $\delta^{13} \mathrm{C}_{\text {org. }}$. B. Pseudo van-Krevelen diagram of hydrogen index $(\mathrm{HI})$ and oxygen index $(\mathrm{OI})$ contents. 